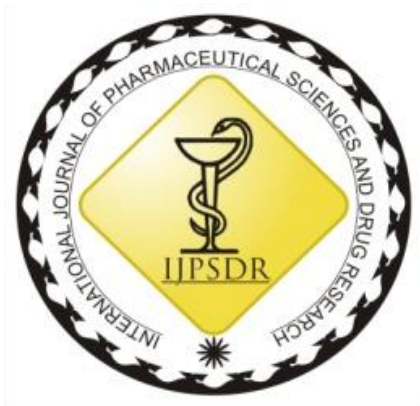

ISSN: 0975-248X

RESEARCH ARTICLE CODEN (USA): IJPSPP

$(\mathrm{cc})$ EY-NC-SA

\title{
Evaluation of In-vitro Anticancer Activity and Quantitation of Active Ingredient of Adansonia digitata L. Fruit
}

\author{
Sandeep Dilip Kadam*, M. S. Kondawar \\ Department of Quality Assurance, Appasaheb Birnale College of Pharmacy (ABCP), Sangli-416416, \\ Maharashtra, India
}

Copyright (C) 2019 Sandeep Dilip Kadam et al. This is an open access article distributed under the terms of the Creative Commons AttributionNonCommercial-ShareAlike 4.0 International License which allows others to remix, tweak, and build upon the work non-commercially, as long as the author is credited and the new creations are licensed under the identical terms.

\begin{abstract}
In the world cancer is the major cause of death. Adansonia digitata L is commonly called as baobab belongs to Family Bombacaceae. Due to the high cost and toxic side effects like Bone marrow suppression, hepatotoxicity, nephrotoxicity, Immunosuppression, teratogenicity etc. of chemotherapeutic agents. So, for the proper controlling on cancer the trends of people are moving towards natural therapies. In light to above, in present research $A$. digitata $\mathrm{L}$ is selected for evaluation of in-vitro anticancer activity based on its reported phytoconstituents of fruit and quantitation of active principle of it. The extracts of fruit pulp, seed, and its combination were obtained using solvents like water, ethanol and n-hexane by maceration technique (Aqueous) and Soxhlet extraction method (organic). This extracts were used for further research possesses phytochemical constituents like Carbohydrates, tannins, Saponins, vitamins, alkaloids, terpenoids, phenol, glycoside flavonoids, steroids, etc. in-vitro antioxidant activity were evaluated via free scavenging assay by using DPPH assay method. Further in-vitro anticancer activity was evaluated against three human cancer cell lines MCF-7 (breast cancer cell line), Hep-G2 (liver cancer cell line) and COLO-205 (colon cancer cell line) using Brine Shrimp Lethality Assay (BSLA), Tryphan Blue Dye Cell Exclusion Assay (TBDCEA) and MTT assay. The quantitation of active ingredients Vit. $\mathrm{C}$ and Squalene from extracts was done by using titration method and HPLC method respectively. Formulation possesses highest percent antioxidant capacity (49.36). In BSLA formulation possesses highest rate of percent mortality than other extracts. In TBCE assay and in MTT assay formulation gives more significant effect in Hep-G2 liver cancer cell line than remaining cell lines. These findings introduce $A$. digitata $\mathrm{L}$ as potentially useful as anti-cancer agent. Further research is required to elucidate its specific mechanism of action and exact active principle responsible for action.
\end{abstract}

Keywords: A. digitata L, Anticancer activity, Cell lines, Antioxidant capacity, Quantitation.

DOI: 10.25004/IJPSDR.2019.110613

Int. J. Pharm. Sci. Drug Res. 2019; 11(6): 358-369

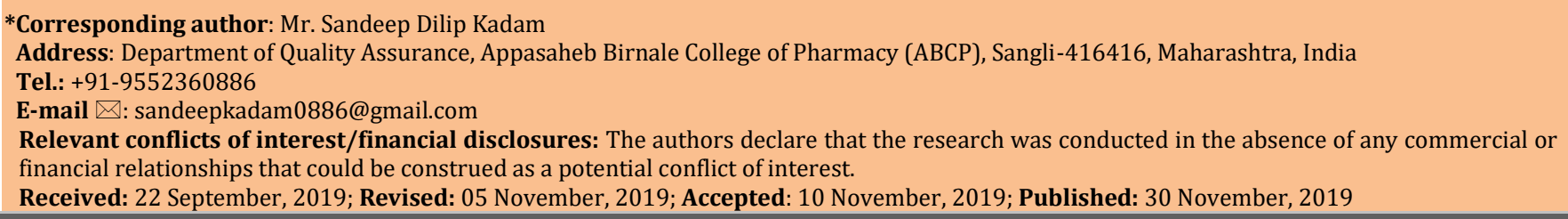

\section{INTRODUCTION}

The WHO describes cancer as a common type of a wide group of diseases marked by the production of unusual cells beyond their controlled boundaries, which can then extend too many other organs that also known as neoplasms and malignant tumours. In the world, cancer is the major cause of death. In year 2015, 8.8 million deaths were due to cancer. The most common 
type of cancer in males is liver, stomach, colorectal, prostrate and lung cancer, while females suffer from cervix, breast, stomach and lung cancer. Global projected death rate of increased by 45 percent in 20082030 and about 70 percent of the cancer death in year 2008 occurred in developed and undeveloped countries, 1.5 million population was died every year by tobacco linked cancer. [1] In metropolitan cities reported that breast cancer attacked on women populations in India viewed by ICMR. Stomach cancer that also helps in to increases population of cancer patient and having fifth rank, prevalence of stomach cancer was found in high in Mizoram state. The cancer producing factors are tobacco products, indoor outdoor pollution, hazardous chemicals, radiation and infection. [2] The treatments on cancer are carried out by different types of methods that are available during last decade of $20^{\text {th }}$ century by surgery, radiation and using chemotherapeutic drugs. Now a days, advanced treatment like Antiangiogenic chemotherapy, targeted treatments, RNA expression proliferation techniques as well as proteomic are used to cure the cancer. [3] The wide or routine uses of chemotherapy agent lead to produce toxic effect on body more than cancer cell for example 5-fluorouracil is commonly used chemotherapeutic agent but that produce cardiotoxicity and myotoxicity. The pharmacological activity associated with natural product have been recognized, however from an average 35,000 plant species may having potential anticancer activities and around 3,000 species of plant have been showed reproducibly anticancer activity, reported by NCI. [4] The research technology interest focuses towards naturally occurring or derived compound as they are easily available and having fewer prices with fewer side effects compared to current treatment of chemotherapy.

Due to the high cost and toxic side effects like Bone marrow suppression, hepatotoxicity, nephrotoxicity, Immunosuppression, teratogenicity of chemotherapeutic agents. So, for the proper controlling on cancer the trends of people are moving towards natural therapies. Plants are an active source of chemotherapeutic agent and more than 60 percent of anticancer agents come from natural origin including herbs, microorganisms and aquatic source. Although various anti-cancer agents are obtained from medicinal plants, there are still a range of plants that have capacity for anticancer but have not been fully found or studied. Almost 14,000 plant extracts screened by National Institute for Cancer for chemotherapeutic activity such as using plant-derived products to treat cancer, adverse side effects may be reduced. A limited plant derivative is currently being used for cancer treatment. However, a various plant products exist that have represents precise anti-cancer properties in vitro. The baobab is commonly used plant species having multipurpose use for food and medicine. The baobab plant possesses some pharmacological activities include, prebiotic like activity, analgesic, antipyretic activity, antioxidant activity antidiarrheal properties, anti-dysenteric activity and anti-inflammatory. [4-6] Hence it may possess the anticancer activity due to occurrence of active chemical constituent like vitamin C, flavonoids. Phytosterols, amino acid, fatty acid, mineral and also Al-Qawari et al in year 2003, state that the triterpenoids beta-sisosterol, ursolic acid and betaamyrin palmitate also present in the fruit and Bianchi et al in year 1982, reported that the fruits of Adansonia, A. grandieri and A. suarezensis. Both contain sitosterol, 4demethylsterol, gamma-tocopherol and squalene as major components therefore, the necessity to attention on assessing whether these extracts are likely to be the source of anticancer or cytotoxicity. ${ }^{[7]}$ Hence $A$. digitata $\mathrm{L}$ is selected for evaluation of anticancer activity based on its reported phytoconstituents in the fruit of $A$. digitata L. and further anticancer activity will evaluate on cell lines by in vitro methods and also quantitation of its active ingredient in present research work.

\section{MATERIALS AND METHODS}

Collection and authentication of plant

The fruits of plant $A$. digitata $\mathrm{L}$ were collected from the local regions of Shirala \& Sangli in the month of October to December 2018. The plant was authenticated by Dr. M. D. Wadmare, Asso. Prof. \& Head, Department of Botany, Kasturbai Walchand College, Sangli.

\section{Preparation of extract}

Pre-extraction process

The dried fruits were cracked by help of Sharpe edge knife, further Pulp were separated from seed. Then seeds and pulp was dried under shade.

\section{Soxhlet extraction method}

Preparation of Ethanolic seed and pulp extracts of $A$. digitata L plant

The dried pulp and seeds of fruit were grinded to a fine powder using a mechanical grinder. From that $100 \mathrm{~g}$ fine powder of pulp, seed and there mixture of equal quantity were separately weighed and extracted with ethanol (at a boiling point of $45-70^{\circ} \mathrm{C}$ ) in a Soxhlet extraction apparatus for 18 hours. Then solvent were evaporated by reduced pressure condition in automatic rotary evaporator. The final extracted pulp, seed and there mixture was weighed and percentage yield was calculated.

Preparation of n-Hexane seed and pulp extract of $A$. digitata L plant

The dried pulp and seed of fruit were grinded to a fine powder using a mechanical grinder. From that take 100 $\mathrm{g}$ of fine powder of pulp, seed and there mixture of equal quantity were separately weighed and extracted with n-Hexane (at a boiling point of $45-70^{\circ} \mathrm{C}$ ) in a Soxhlet extraction apparatus for $6 \mathrm{hrs}$. The solvent were removed with lowest pressure condition in automatic rotary evaporator. The final extracted pulp, seed and there mixture was weighed and percentage yield was calculated. 


\section{Maceration extraction method}

Preparation of aqueous seed and pulp extracts of $A$. digitata L plant

The dried pulp and seed of fruit were grinded to a fine powder using a mechanical grinder. About $100 \mathrm{~g}$ of fine powder of pulp, seed and there mixture of equal quantity were separately weighed and placed them for cold maceration with 10 percent chloroform water in $500 \mathrm{ml}$ of conical flask for about 7 days at normal room temperature. The flask was tightly plugged with absorbent cotton and was stirred or shakes periodically using rotary shaker till complete saturation. After the maceration, the marc or residual cake was pressed in muslin cloth and filtrate and respective filtrates were boiled to concentrate. The \% (percentage) yields of extracts were calculated by using following formula

Percentage yield of extract $=$ Weight of extract $(\mathrm{g}) /$ Weight of sample $(\mathrm{g}) \times 100$

Formulation (combination of aqueous pulp extracts and seed oil) of $A$. digitata L Fruit Pulp with the Seed Oil [8]

$10 \mathrm{~g}$ of aqueous pulp extract $A$. digitata $\mathrm{L}$ fruit was transferred to $100 \mathrm{ml}$ of volumetric flask, Added $2 \mathrm{ml}$ oil from n-Hexane seed extract and content were diluted with $100 \mathrm{ml}$ distilled water. The obtained extract or compound was kept in sonicator continuously at the $28-32^{\circ} \mathrm{C}$ temperature for $60 \mathrm{~min}$ then it was kept in centrifuge machine for few min to settle down large particles and the superficial layer was collected. The prepared solution was filtered through sterilized cotton and the filtered solution was kept into refrigerator at temperature $8-10^{\circ} \mathrm{C}$ for further use.

Investigation of phytoconstituents

Phytochemical tests were carried and to finding the presence of phytoconstituents like. Proteins, Glycosides, Carbohydrates, Flavonoids, Alkaloids, Steroids and Tannins in the fruit, fruit pulp and seed oil of $A$. digitata $\mathrm{L}$.

Determination of antioxidant capacity by DPPH method [9]

\section{Preparation of DPPH Reagents}

The reagent stock solution prepared by adding $24 \mathrm{mg} 2$, 2-Diphenyl-1-picrylhydrazyl powder in $100 \mathrm{ml}$ methanol and shakes the solution to complete dissolve. Then it was kept in a refrigerator in amber colored bottle till further use. The radicals working solution was ready by diluting the stock solution with methanol to get an absorption of approximately $0.98 \pm 0.02$ at the wavelength $517 \mathrm{~nm}$.

Preparation standard (Ascorbic acid) and control

Specific amount of test tube required for experiment was taken and in each test tube added $3 \mathrm{ml}$ of DPPH working solution. For standard, $100 \mu \mathrm{l}(1.76 \mathrm{mg}$ powder of "Vitamin C" in $1 \mathrm{ml}$ methanol Ascorbic acid solutions were added and for control $100 \mu$ l of methanol was added. Further, incubated all the test tubes at $37^{\circ} \mathrm{C}$ for half hour and absorbance were measured at $517 \mathrm{~nm}$ using Spectrophotometry. The percentage antioxidant capacity estimated by following formula

Antioxidant capacity $(\%)=[($ Ac-As $) / A c] \times 100$

Where, $\mathrm{Ac}=$ Absorbance of control solution, As = Absorbance of sample solution

Preparation of sample

Specific amount of test tube required for experiment was taken and in each test tube added $3 \mathrm{ml}$ of DPPH working solution. For sample, $100 \mu \mathrm{l}(1 \mathrm{mg} / \mathrm{ml})$ test as plant extracts were added. Further, incubated all the test tubes at $37^{\circ} \mathrm{C}$ for $30 \mathrm{~min}$ and absorbance were measured at $517 \mathrm{~nm}$ using Spectrophotometry. The percentage antioxidant capacity was calculated using the following formula

Antioxidant capacity $(\%)=[($ Ac-As $) / A c] \times 100$

Where, $\mathrm{Ac}=$ Absorbance of control solution, As = Absorbance of sample solution

Determination of Anticancer activity

In-vitro methods of cytotoxicity screening [9-11]

The following in-vitro methods used for evaluation of anticancer activity,

a. Brine shrimp lethality assay (BSLA)

b. Trypan blue dye cell exclusion assay (TBDCEA)

c. MTT assay

Brine shrimp lethality assay

Preparation of seawater

Artificial sea water for hatching of brine shrimp was made with respect to the hatching instruction given by Aquatic remedies; Chennai, India. Crude $25 \mathrm{gm} / \mathrm{L}$ sea salt (without iodine) and dried yeast having quantity 6 mg was taken, added into the one litter of distilled water and then filtered through filter paper to obtained clear transparent solution.

Hatching of Brine Shrimp

Artemia salina leach (brine shrimp eggs) collected from Aquatic remedies; Chennai, India was used as the test organism. The $3.5 \mathrm{~L}$ of artificial prepared sea water was filled to the egg hatching chamber and one brine shrimp eggs containing capsule of was added to dark (black) side of the compartment then this side was covered by lid. After two days of hatching the shrimp got matured and nauplii were collected and used for study. During the hatching moment, constant availability of oxygen was given. The matured shrimps are drained to the light (phototaxis) and so egg-shell free nauplii from the brightened portion of the tank have been collected. Using pipette nauplii were taken from the fish tank and diluted it to increase visibility in fresh clear sea water and with the help of micropipette 10 nauplii were taken.

Preparation of test solutions of extracts

Samples solution or test solution was prepared by adding $10 \mathrm{mg}$ of each extracts in $20 \mu \mathrm{l}$ of dimethyl sulfoxide and volume make up to $10 \mathrm{ml}$ quantity of distilled water to form $1000 \mu \mathrm{g} / \mathrm{ml}$ of final stock solution. From Prepared stock the solution, $100 \mu \mathrm{l}$, 
$200 \mu \mathrm{l}, 500 \mathrm{ul}, 1000 \mu \mathrm{l}$, and $2500 \mu \mathrm{l}$ were removed and final volume was made up to $5 \mathrm{ml}$ with distilled water to achieve the final concentration of drug 20, 50, 100, 200 and $500 \mu \mathrm{g} / \mathrm{ml}$ for each solution. Triplicate form of solution was made for individually dose level. One vial was considered as Control by adding equal quantity of artificial sea water.

\section{Bioassay [10]}

The bioassay experiment was performed accordance with Meyer et al. 1982 they described procedures for bioassay. Naupalii were collected in a glass pipette or dropper filled with water, and ten nauplii were added to each drug conc. vial containing $4.5 \mathrm{ml}$ artificial sea water (solution with specific amount of yeast powder). In each experiment, $0.5 \mathrm{ml}$ of extracts was added into artificial sea water with $4.5 \mathrm{ml}$ quantity of solution at different range concentrations $20-500 \mu \mathrm{g} / \mathrm{ml}$ respectively. In control vial contain $4.5 \mathrm{ml}$ of artificial prepared sea water and $0.5 \mathrm{ml}$ of distilled water. The vial was kept under light condition. After 24 hours survival of nauplii were counted by $3 X$ magnifying glass against dark background, and the percentage lethality and $\mathrm{LC}_{50}$ values was estimated by dosedependent response data were converted into a straight line by means of a treadline fit linear regression analysis (MS-Excel version-10); and the $\mathrm{LC}_{50}$ was resulting from the best fit line obtained.

Trypan blue dye cell exclusion assay (TBDCEA) ${ }^{[8-9]}$

Preparation of Trypan blue

$100 \mathrm{mg}$ trypan blue dye was dissolved in $100 \mathrm{ml}$ Phosphate buffer saline and stored at $4^{\circ} \mathrm{C}$ into the refrigerator.

Preparation of Standard drug solution

Samples of standard prepared by dissolved $10 \mathrm{mg}$ quantity of 5-Fluorouracil in $20 \mu \mathrm{l}$ of dimethyl sulfoxide and volume make up to $10 \mathrm{ml}$ with phosphate buffer saline (PBS-7.4 pH), to got $1000 \mu \mathrm{g} / \mathrm{ml}$ concentration stock solution. From prepared stock solution 10, 100, $500 \mu \mathrm{l}$ was took and adjusted up to $10 \mathrm{ml}$ (in $10 \mathrm{ml}$ container/vial capacity) with Phosphate buffer saline solution to got the final drug conc for solution come to be at $10,100,500 \mu \mathrm{g} / \mathrm{ml}$ concentration.

\section{Preparation of Sample Solution}

The extracts Samples solution were made by adding 10 $\mathrm{mg}$ of extract in $20 \mu \mathrm{l}$ of dimethyl sulfoxide and volume made with $10 \mathrm{ml}$ of Phosphate buffer saline (PBS), to get $1000 \mu \mathrm{g} / \mathrm{ml}$ stock solution. From this stock $100 \mu \mathrm{l}$, $1000 \mathrm{\mu l}$ and $5000 \mu \mathrm{l}$ were took and final level made up to $10 \mathrm{ml}$ (in $10 \mathrm{ml}$ vial storing capacity) with Phosphate buffer saline solution to become the final drug conc. $10 \mu \mathrm{g} / \mathrm{ml}, 100 \mu \mathrm{g} / \mathrm{ml}$, and $500 \mu \mathrm{g} / \mathrm{ml}$. triplicates were made for each and every dose level. In one vial add equal volumes of $0.2 \%$ dimethyl sulfoxide with Phosphate buffer saline and set as Control.

\section{Procedure for cytotoxicity assay}

In the stock cell suspension, cell count determined and cells were found MCF7, COLO205 and HePG2 cells line $2.7 \times 10^{5} / 0.1 \mathrm{ml}$. From this stock, cell suspension was taken in micro wells of microtiter well plates.
In the $1^{\text {st }}$ well added only $0.1 \mathrm{ml}$ volume of dimethyl sulfoxide $(0.1 \% \mathrm{v} / \mathrm{v}$ with dimethyl sulfoxide-7.4 $\mathrm{pH})$ and set as control group or well. In the next 3 wells, having concentration extending from 10, 100 and $500 \mu \mathrm{g} / \mathrm{ml}$ of 5 -Fluorouracil were added in series of 3 micro wells in Microtiter well plate considered as standard groups. In the remaining wells, $0.1 \mathrm{ml}$ extracts concentration extending from 10,100 and $500 \mu \mathrm{g} / \mathrm{ml}$ were added in respective micro wells considered as test groups. Further, microtiter well plate was incubated at temperature $37^{\circ} \mathrm{C}$ and $7 \%$ carbon dioxide incubator for period of three hours. After the incubation, in each microwell of microtiter well plate individually. $0.1 \mathrm{ml}$ of trypan blue was added and mixed well.

\section{Cell counting}

The total numbers of dead and living cells on Neuber's chambers of all the respective four corner squares were counted by using haemocytometer and the total number of live cells or dead cell was calculated by using following formula

\section{Total number of live cells $=\mathrm{A} \times \mathrm{B} \times \mathrm{C} \times 10^{4}$}

Where, $\mathrm{A}=$ Mean number of unstained cells (Viable cells); $\mathrm{B}=$ Dilution factor of TBDCEA solution (1:5); $\mathrm{C}=$ Mean of dead cells number. $10^{4}=$ Conversion of $0.1 \mathrm{~mm}^{3}$ to $\mathrm{ml}$.

Percentage of cell viability for cytotoxicity was calculated using following formula

$\%$ Viability $=$ Viable cell count $/$ Total cell count $\times 100$

\section{MTT assay}

\section{Preparation of Standard drug solution}

standard drug sample was made by adding $10 \mathrm{mg}$ of 5Fluorouracil in 20 $\mu$ l of dimethyl sulfoxide and dissolve the drug further volume was adjusted with $10 \mathrm{ml}$ Phosphate buffer saline (PBS), to get $1000 \mu \mathrm{g} / \mathrm{ml}$ stock solution. From this stock $20 \mu l$ quantity was taken and volume adjusted with $10 \mathrm{ml}$ Phosphate buffer saline solution to get the drug conc. $20 \mu \mathrm{g} / \mathrm{ml}$.

\section{Preparation of Sample Solution}

Samples solution of the extracts were prepared by adding $10 \mathrm{mg}$ of extract in $20 \mu \mathrm{l}$ of dimethyl sulfoxide and volume made up to $10 \mathrm{ml}$ with Phosphate buffer saline (PBS), to get $1000 \mu \mathrm{g} / \mathrm{ml}$ stock solution. From this stock $100 \mu \mathrm{l}, 1000 \mu \mathrm{l}$ and $5000 \mu \mathrm{l}$ were added and volume was filled up to $10 \mathrm{ml}$ (in $10 \mathrm{ml}$ storing capacity vial) with PBS solution to get the final drug conc. $10 \mu \mathrm{g} / \mathrm{ml}$, $100 \mu \mathrm{g} / \mathrm{ml}$, and $500 \mu \mathrm{g} / \mathrm{ml}$. solution was prepared in Triplicate for every single dose level. Equal volumes of $0.2 \%$ dimethyl sulfoxide Phosphate buffer saline added in Control.

\section{Experimental procedure}

Cells were incubated at a concentration of $1 \times 10^{5}$ cells $/ \mathrm{ml}$ in culture medium for one day at the temperature of $37^{\circ} \mathrm{C}$. The incubator maintained at 5 percent level of carbon dioxide. Cells were cultured at a concentration $(70 \mu \mathrm{l}) 10^{5} \mathrm{cells} /$ well in $100 \mu \mathrm{l}$ culture medium and $100 \mu \mathrm{l}$ extracts of various concentrations 
$(10 \mu \mathrm{g} / \mathrm{ml}, 100 \mu \mathrm{g} / \mathrm{ml}, 500 \mu \mathrm{g} / \mathrm{ml})$ and $0.1 \mathrm{ml}$ of $5-\mathrm{FU}$ into micro plates respectively (tissue culture grade, and 96 wells) as shown in Table 1.

Table 1: Apportionment of behaviour in micro wells for MTT assay

\begin{tabular}{ccc}
\hline Well & Features & Contents \\
\hline \multirow{2}{*}{ First well } & - & $0.2 \% \mathrm{v} / \mathrm{v}$ dimethyl sulfoxide in \\
& & phosphate buffer saline $270 \mu \mathrm{l}$ \\
Second well & Control & $70 \mu \mathrm{l}+$ phosphate buffer saline \\
& & $100 \mu \mathrm{l}$ \\
& & Culture media $100 \mu \mathrm{l}+$ Cell lines \\
Remaining well & Test groups or & $70 \mu \mathrm{l}+$ Extracts $100 \mu \mathrm{l}$ (test \\
& Positive control & substance) or Standard \\
\hline
\end{tabular}

Dimethyl sulfoxide and $0.2 \%$ in Phosphate buffer saline Control wells were incubated with and cell line. In triplicate manner all presented samples solutions were incubated. Controls were maintained to determine the control cell survival and the measurement of live cells after culture.

Cell cultures were stored at $37^{\circ} \mathrm{C}$ for 24 hours at and 5 percent carbon dioxide in carbon dioxide incubator. The completion of incubation, the culture medium was completely removed and $20 \mu$ of MTT reagent was added (conc. $5 \mathrm{mg} / \mathrm{ml}$ in Phosphate buffer saline). Cells were incubated for four hours at $37^{\circ} \mathrm{C}$ temperature in Carbon dioxide Incubator after addition of MTT reagents. Formazan crystal formation in the well was observed with help of microscope. The MTT was reduces their yellow color solution to dark purple coloured formazan indicated due to live cells (viable cells) only. Medium was completely removed and Added $20 \mu$ l of dimethyl sulfoxide and incubate at $37^{\circ} \mathrm{C}$ kept wrapped with aluminium foil sheet for $10 \mathrm{~min}$. All samples were analyzed in Triplicate by determination the absorbance of each sample by a microplate analyzer wavelength at $450 \mathrm{~nm}$.

\footnotetext{
Percent Cytotoxicity $=$

(Reading of control - Reading of treated cells) / Reading of control $\times 100$
}

Quantitation of active ingredients from extract

Vitamin C [12]

Identification of Vitamin $\mathrm{C}$ from aqueous pulp extract by chemical method

$1 \mathrm{ml}$ diluted solution of aqueous pulp extract then added some drops of $5 \% \mathrm{w} / \mathrm{v}$ sodium fresh nitroprusside solution and $2 \mathrm{ml}$ dil. $\mathrm{NaOH}$ solution. Add $0.6 \mathrm{ml}$ of $\mathrm{HCl}$ drop wise and stirred, the yellow colour turned to blue. Diluted solution of extract solution to it add few $\mathrm{ml}$ of 2, 6dichlorophenolindophenol solution, the solution is decolorized.

Determination of Vitamin C from aqueous pulp extract by Titration method [13]

Weighed about $0.1 \mathrm{~g}$ of aqueous pulp extract of $\mathrm{A}$. digitata $\mathrm{L}$ fruit in $250 \mathrm{ml}$ titrating flask and added in a combination with $100 \mathrm{ml}$ of pure boiled and cooled water and $25 \mathrm{ml} 1 \mathrm{M} \mathrm{H}_{2} \mathrm{SO}_{4}$ and Directly titrated against $0.05 \mathrm{M} \mathrm{I}_{2}$ solution using starch solution as indicator till a persistent blue or violet colour was obtained. Then recorded the final burrate reading and amount of Vitamin C was calculated by following factor.

Each $\mathrm{ml}$ of $0.05 \mathrm{M}$ Iodine solution equivalent to $0.008806 \mathrm{~g}$ of Vit. C

\section{Squalene}

Identification Squalene from n-hexane seed extract by thin layer chromatography [14]

Thin Layer Chromatography Plate Preparation procedure

Chromatography was prepared by using silica gel G material act as adsorbent layer. Silica gel slurry or paste was made in distilled water. The silica gel was poured to maintained thickness get of $0.3 \mathrm{~mm}$ over appropriately clean and waterless glass slide having dimensions $10 \mathrm{~cm} \times 20 \mathrm{~cm}$ by an applicator. The plate was prepared at temperature $110 \pm 5^{\circ} \mathrm{C}$ for one hour. Further this, application of sample (extract dissolved in $\mathrm{n}$ hexane) using capillary and running the TLC plate for the solvent front by the selected mobile phase. Then compare the retention factor of test with retention factor of standard squalene, calculate the retention factor by using formula.

$\mathrm{R}_{\mathrm{f}}$ Value $=$ Distance traveled by sample $/$ Distance traveled by solvent

The details of TLC as

$\begin{array}{ll}\text { Adsorbent } & : \text { Silica gel G } \\ \text { Thickness } & : 0.3 \mathrm{~mm}\end{array}$

Plate or slide dimensions: $10 \times 20 \mathrm{~cm}$

Activation Chamber Temperature: $110 \pm 5^{\circ} \mathrm{C}$

Mobile phase $\quad$ : Hexane: Ethyl acetate $(6: 1)$

Chamber Saturation Time: $10 \mathrm{~min}$

Detecting reagent : Iodine vapours.

Determination of Squalene by HPLC method [15]

Preparation of Standard

Standard stock solution prepared by dissolving $50 \mathrm{mg}$ of squalene in to $100 \mathrm{ml}$ of ethanol. From that $5 \mathrm{ml}$ solution and removed and diluted with $100 \mathrm{ml}$ acetonitrile to get final concentration $25 \mu \mathrm{g} / \mathrm{ml}$.

Preparation of Sample

Extracts samples solutions were carried by in $2 \mathrm{ml}$ quantity of ethanol dissolving $500 \mu \mathrm{l}$ extract. Afterwards the mixture solution was stirred or vortexed in vortex for five minute to achieve proper mixing and was kept for gravity separation funnel for 6 $\mathrm{hr}$ at suitable temperature. Complete separation occurred; $20 \mu 1$ of upper layer was separated and dissolved in $500 \mu \mathrm{l}$ Acetonitrile. These solutions were subjected for analysis. Similarly the blank solution was made by dissolving $20 \mu 1$ ethanol in $500 \mu$ Acetonitrile.

Chromatographic condition

The HPLC method carried out as described by Sri Charan Bindu Bavisetty and Bhaskar Narayan (2015) with some alteration of corresponding selection a C18 column with core shell technology the $30 \mu 1$ injection 
volume set to and $35^{\circ} \mathrm{C}$ temperature of column set for analysis. HPLC grade Acetonitrile having $100 \%$ purity was used as mobile phase having rate of flow 1.5 $\mathrm{ml} / \mathrm{min}$ in program was fixed for half hour an isocratic mode. Detection carried with diode array detector at wavelength $195 \mathrm{~nm}$.

\section{RESULTS AND DISCUSSION}

\section{Collection and Authentication of Plant}

The plant of $A$. digitata $\mathrm{L}$ was collected from the local area of Shirala \& Sangli in the month of October to December 2018. The plant was authenticated by Dr. M. D. Wadmare, Asso. Prof. \& Head, Department of Botany, Kasturbai Walchand College, Sangli.

\section{Physical Evaluation of Extracts}

The Physical evaluation of $A$. digitata $L$ fruit extracts on different solvent by using two types of extraction process i.e. Maceration and Soxhlet extraction and the Physical properties of these extracts are shown in Table 2.

\section{Phytochemical Investigation}

The qualitative preliminary phytochemical investigation of Adansonia digitata L fruit extracts were performed with various chemical solutions or reagents to detect phytoconstituents nature and their occurrence in extracts as follows.

Aqueous pulp extract: Glycosides, Saponins, phenols, steroids tannins, proteins, flavonoids, carbohydrates, alkaloids, and amino acids.

Aqueous seed extract: Carbohydrates, tannins, alkaloids, glycosides, steroids, phenols, flavonoids, and amino acids.

Aqueous seed + pulp extract: Flavonoids, glycosides, steroids, phenols, proteins, Saponins, tannins, carbohydrates and alkaloids.

Ethanol pulp extract: Alkaloids, glycosides, flavonoids, steroids, Saponins, phenols, tannins, proteins, carbohydrates and amino acid.

Ethanol seed extract: Alkaloids, Saponins, flavonoids, steroids, phenols, tannins, glycosides, proteins, amino acid and Carbohydrates.

Ethanol seed + pulp extract: steroids, alkaloids, glycosides, Saponins, tannins, proteins, carbohydrates flavonoids, amino acids and phenols

n-Hexane pulp extract: Phenols, flavonoids, steroids, glycosides, alkaloids tannins and carbohydrates

n-Hexane seed extract: Steroids, glycosides, flavonoids, Saponins, alkaloids phenols, tannins, carbohydrates, , fats and oil.

n-Hexane seed + pulp extract: Alkaloids, glycosides, steroids, Saponins, phenols, tannins, carbohydrates, amino acid, flavonoids, fats and oil.

Determination of antioxidant capacity by DPPH radical scavenging method

The highest \% antioxidant capacity of Aq. Pulp, Ethanolic pulp, n-hexane seed extract and formulation possesses 45.56, 41.77, 43.67, and 49.36 respectively. This mentioned extracts possesses more significant \% antioxidant capacity than other extracts of $A$. digitata L. fruit as shown in Table 3.

Table 2: Solvents, extraction methods organoleptic characters and respective yield from A. digitata $\mathrm{L}$ fruit extracts

\begin{tabular}{|c|c|c|c|c|c|c|}
\hline S. No & Extract & Method & Colour & Odour & Nature & $\begin{array}{c}\% \text { Yield } \\
\text { w/w }\end{array}$ \\
\hline 1. & $\begin{array}{c}\text { Aqueous } \\
\text { pulp extract }\end{array}$ & Maceration & brown & Characteristics & Semisolid & 38 \\
\hline 2. & $\begin{array}{l}\text { Aqueous } \\
\text { seed extract }\end{array}$ & Maceration & $\begin{array}{l}\text { Slightly } \\
\text { white }\end{array}$ & Characteristics & Semisolid & 10 \\
\hline 3. & $\begin{array}{c}\text { Aqueous seed } \\
+ \text { pulp } \\
\text { extract }\end{array}$ & Maceration & $\begin{array}{l}\text { Slightly } \\
\text { brown }\end{array}$ & Characteristics & Semisolid & 15.5 \\
\hline 4. & $\begin{array}{c}\text { Ethanol pulp } \\
\text { Extract }\end{array}$ & $\begin{array}{c}\text { Soxhlet } \\
\text { Extraction }\end{array}$ & $\begin{array}{c}\text { Dark } \\
\text { brown }\end{array}$ & Sweetish & Semisolid & 32 \\
\hline 5. & $\begin{array}{c}\text { Ethanol seed } \\
\text { Extract }\end{array}$ & $\begin{array}{l}\text { Soxhlet } \\
\text { Extraction }\end{array}$ & $\begin{array}{l}\text { Slightly } \\
\text { brown }\end{array}$ & Sweetish & Semisolid & 12.2 \\
\hline 6. & $\begin{array}{l}\text { Ethanol seed } \\
+ \text { pulp extract }\end{array}$ & $\begin{array}{l}\text { Soxhlet } \\
\text { extraction }\end{array}$ & brown & $\begin{array}{l}\text { Slightly } \\
\text { sweetish }\end{array}$ & Semisolid & 11 \\
\hline 7. & $\begin{array}{l}\text { n-Hexane } \\
\text { pulp extract }\end{array}$ & $\begin{array}{l}\text { Soxhlet } \\
\text { Extraction }\end{array}$ & $\begin{array}{l}\text { Slightly } \\
\text { brown }\end{array}$ & characteristics & Semisolid & 25 \\
\hline 8. & $\begin{array}{c}\text { n-Hexane } \\
\text { seed extract }\end{array}$ & $\begin{array}{c}\text { Soxhlet } \\
\text { Extraction }\end{array}$ & $\begin{array}{c}\text { Pale } \\
\text { yellow }\end{array}$ & Characteristics & Liquid & 14 \\
\hline 9. & $\begin{array}{c}\text { n-Hexane } \\
\text { seed + pulp } \\
\text { extract }\end{array}$ & $\begin{array}{l}\text { Soxhlet } \\
\text { extraction }\end{array}$ & $\begin{array}{l}\text { Slightly } \\
\text { brown }\end{array}$ & characteristics & Semisolid & 12.5 \\
\hline
\end{tabular}

Table 3: Antioxidant capacity of A. digitata L fruit extracts.

\begin{tabular}{ccc}
\hline S. No & Extracts & \% Antioxidant capacity \\
\hline 1. & Aqueous pulp extract & 45.56 \\
2. & Aqueous seed extract & 29.74 \\
3. & Aqueous seed + pulp extract & 31.64 \\
4. & Ethanol pulp extract & 41.77 \\
5. & Ethanol seed extract & 25.94 \\
6. & Ethanol seed + pulp extract & 32.91 \\
7. & N Hexane pulp extract & 31.64 \\
8. & N Hexane seed extract & 43.67 \\
9. & N Hexane seed + pulp extract & 33.54 \\
10 & Formulation & 49.36 \\
\hline
\end{tabular}

\section{Determination of Anticancer activity \\ Brine Shrimp Lethality bioassay (BSLA)}

The results of BSLA on crude extracts like Aqueous pulp, seed and combination of seed and pulp, Then Ethanolic pulp, seed and its combination extracts likewise n-hexane pulp, seed and its combination and formulation of $A$. digitata $\mathrm{L}$ fruit were done. From above extracts the specific three aqueous pulp, ethanol pulp and n-Hexane seed extracts and formulation possesses very significant activity. The percentage mortality increases with respect to concentration of extracts. These are described as the \% mortality by aqueous pulp extract respective plant were ranging from $10.00 \%$ to $56.66 \%$ followed by percentage mortality of Ethanolic pulp extract was found in between $13.33 \%$ to $60 \%$ further the percentage mortality of n-Hexane seed ranging from $10 \%$ to $60 \%$ percent and last of all formulation possesses highest percent mortality which ranges up to $63.33 \%$, so that $500 \mu \mathrm{g} / \mathrm{ml}$ concentration formulation having highest rate of percentage mortality than other extracts in respective method. As we discussed earlier, \% mortality increased with respect to concentration of extracts and formulation. Then $\mathrm{LC}_{50}$ is helpful to express toxicity of extract and it is generally valorized either by comparison to Clarkson's or Mayer's toxicity index. 
Sandeep Dilip Kadam et al. / Evaluation of In-vitro Anticancer Activity and Quantitation of Active

Table 4: Effect of 5-FU (Std.) on BSLA

\begin{tabular}{|c|c|c|c|c|c|c|}
\hline \multirow[t]{2}{*}{ S. No } & \multirow[t]{2}{*}{$\begin{array}{c}\text { Concentration } \\
(\mu \mathrm{g} / \mathrm{ml})\end{array}$} & \multicolumn{3}{|c|}{$\begin{array}{c}\text { Out of } 10 \text { number } \\
\text { of nauplii } \\
\text { becomes dead }\end{array}$} & \multirow{2}{*}{\multicolumn{2}{|c|}{$\begin{array}{l}\text { Total dead } \\
\text { nauplii out of } \% \text { Mortality } \\
\quad 30\end{array}$}} \\
\hline & & T1 & T2 & T3 & & \\
\hline 1 & 20 & 4 & 4 & 2 & 10 & 33.33 \\
\hline 2 & 50 & 5 & 3 & 4 & 12 & 40.00 \\
\hline 3 & 100 & 6 & 4 & 6 & 13 & 43.33 \\
\hline 4 & 200 & 6 & 4 & 7 & 17 & 56.66 \\
\hline 5 & 500 & 8 & 9 & 9 & 26 & 86.66 \\
\hline
\end{tabular}

Table 5: Effect of Aqueous pulp extract on BSLA

\begin{tabular}{ccccccc}
\hline S. No & $\begin{array}{c}\text { Concentration } \\
(\boldsymbol{\mu} \mathbf{g} / \mathbf{m l})\end{array}$ & $\begin{array}{c}\text { Out of 10 number } \\
\text { of nauplii } \\
\text { becomes dead }\end{array}$ & $\begin{array}{c}\text { Total dead } \\
\text { nauplii out of }\end{array}$ & \% Mortality \\
\cline { 3 - 5 } & & $\mathbf{T} 1$ & $\mathbf{T 2}$ & $\mathbf{T 3}$ & & \\
\hline 1 & 20 & 1 & 1 & 1 & 3 & 10 \\
2 & 50 & 4 & 1 & 1 & 6 & 20 \\
3 & 100 & 3 & 2 & 3 & 8 & 26.66 \\
4 & 200 & 4 & 5 & 5 & 14 & 46.66 \\
5 & 500 & 6 & 6 & 5 & 17 & 56.66 \\
\hline
\end{tabular}

Table 6: Effect of Ethanol pulp extract on BSLA

\begin{tabular}{|c|c|c|c|c|c|c|}
\hline \multirow[t]{2}{*}{ S. No. } & \multirow[t]{2}{*}{$\begin{array}{c}\text { Concentration } \\
(\mu \mathrm{g} / \mathrm{ml})\end{array}$} & \multicolumn{3}{|c|}{$\begin{array}{c}\text { Out of } 10 \text { number } \\
\text { of nauplii } \\
\text { becomes dead }\end{array}$} & \multirow{2}{*}{$\begin{array}{c}\text { Total dead } \\
\text { nauplii out of } \\
30\end{array}$} & \multirow{2}{*}{$\%$ Mortality } \\
\hline & & T1 & T2 & T3 & & \\
\hline 1 & 20 & 1 & 2 & 1 & 4 & 13.33 \\
\hline 2 & 50 & 4 & 1 & 1 & 6 & 20 \\
\hline 3 & 100 & 3 & 4 & 4 & 11 & 36.66 \\
\hline 4 & 200 & 4 & 5 & 5 & 14 & 46.66 \\
\hline 5 & 500 & 5 & 6 & 7 & 18 & 60 \\
\hline
\end{tabular}

Table 7: Effect of $\mathbf{n}$-Hexane seed extract on BSLA

\begin{tabular}{|c|c|c|c|c|c|c|}
\hline \multirow[t]{2}{*}{ S. No } & \multirow[t]{2}{*}{$\begin{array}{c}\text { Concentration } \\
(\mu \mathrm{g} / \mathrm{ml})\end{array}$} & \multicolumn{3}{|c|}{$\begin{array}{c}\text { Out of } 10 \text { number } \\
\text { of nauplii } \\
\text { becomes dead }\end{array}$} & \multirow[t]{2}{*}{$\begin{array}{c}\text { Total dead } \\
\text { nauplii out of } \\
30\end{array}$} & \multirow[t]{2}{*}{$\%$ Mortality } \\
\hline & & T1 & T2 & T3 & & \\
\hline 1 & 20 & 1 & 0 & 2 & 3 & 10 \\
\hline 2 & 50 & 1 & 2 & 2 & 5 & 16.66 \\
\hline 3 & 100 & 3 & 2 & 3 & 8 & 26.66 \\
\hline 4 & 200 & 4 & 3 & 4 & 11 & 36 \\
\hline 5 & 500 & 6 & 7 & 5 & 18 & 60 \\
\hline
\end{tabular}

Table 8: Effect of formulation on BSLA

\begin{tabular}{|c|c|c|c|c|c|c|}
\hline \multirow[t]{2}{*}{ S. No } & \multirow[t]{2}{*}{$\begin{array}{c}\text { Concentration } \\
(\mu \mathrm{g} / \mathrm{ml})\end{array}$} & \multicolumn{3}{|c|}{$\begin{array}{c}\text { Out of } 10 \text { number } \\
\text { of nauplii } \\
\text { becomes dead }\end{array}$} & \multirow{2}{*}{$\begin{array}{c}\text { Total dead } \\
\text { nauplii out of } \\
30\end{array}$} & \multirow[t]{2}{*}{$\%$ Mortality } \\
\hline & & T1 & T2 & T3 & & \\
\hline 1 & 20 & 1 & 2 & 0 & 3 & 10 \\
\hline 2 & 50 & 2 & 3 & 1 & 6 & 20 \\
\hline 3 & 100 & 4 & 2 & 3 & 9 & 30 \\
\hline 4 & 200 & 6 & 4 & 3 & 13 & 43.33 \\
\hline 5 & 500 & 7 & 5 & 7 & 19 & 63.33 \\
\hline
\end{tabular}

Table 9: Calculation of $\mathrm{LC}_{50}$ by linear - regression analysis

\begin{tabular}{cccc}
\hline Treatments & Dose $(\boldsymbol{\mu g} / \mathrm{ml})$ & $\begin{array}{c}\text { Mean \% mortality after } \\
\text { 24 hours (Mean } \pm \text { SEM) }\end{array}$ & $\begin{array}{c}\mathbf{L C}_{50} \\
(\boldsymbol{\mu} \mathrm{g} / \mathrm{ml})\end{array}$ \\
\hline \multirow{5}{*}{ - } & 20 & $33.33 \pm 1.137$ & \\
Fluorouracil & 50 & $40.00 \pm 0.1155$ & \\
& 100 & $43.33 \pm 0.7679$ & 245.57 \\
& 200 & $56.62 \pm 0.8836$ & \\
\hline
\end{tabular}

According to Clarkson's toxicity index criteria, the $\mathrm{LC}_{50}$ values of aqueous pulp, ethanol pulp, n-hexane seed and formulation are lies between $100-500 \mu \mathrm{g} / \mathrm{ml}$ that are $370.64,342.23,370.37$ and $340.13 \mu \mathrm{g} / \mathrm{ml}$ respectively which are considered as above mentioned extract possesses medium toxicity which is analogous to standard drug 5-flurouracil (5-FU). Whereas, according to Mayer's toxicity index all above mentioned extracts and a formulation are toxic in nature as they possesses $\mathrm{LC}_{50}<1000 \mu \mathrm{g} / \mathrm{ml}$.

\section{Brime shrimp leathality bioassay of $5-\mathrm{FU}$}

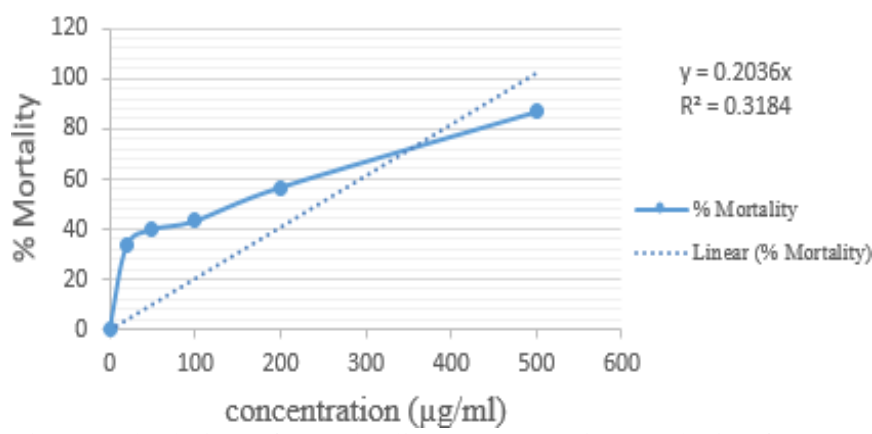

Fig. 1: Calculation of $\mathrm{LC}_{50}$ by linear - regression analysis of $5-\mathrm{FU}$ at different concentrations.

\%Brime shrimp leathality bioassy of aquoeus pulp

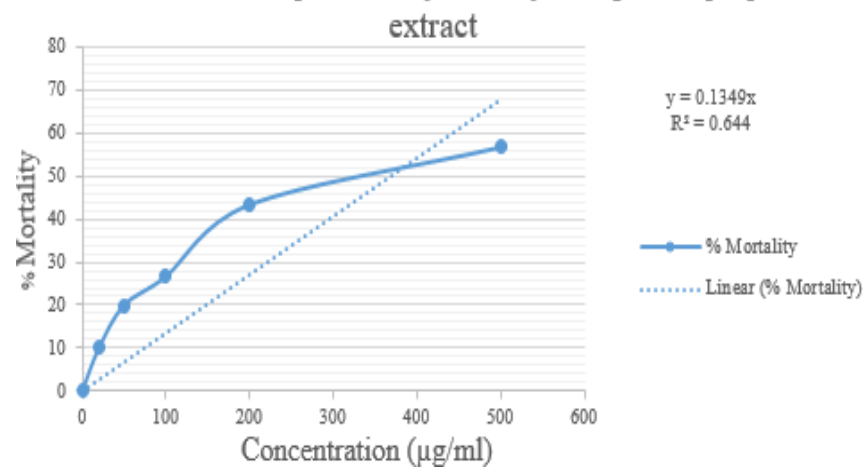

Fig. 2: Calculation of $\mathrm{LC}_{50}$ by linear - regression analysis of aqueous pulp extract at different concentrations

$\%$ Brime shrimp leathality bioassay of ethanol pulp extract

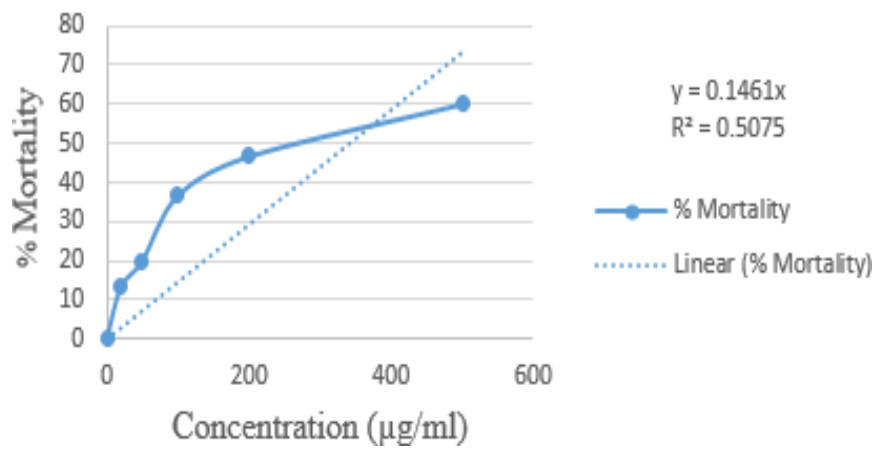

Fig. 3: Calculation of $\mathrm{LC}_{50}$ by linear -regression analysis of ethanol pulp extract at different concentrations.

Brime shrimp leathality bioassay of $\mathrm{n}$-Hexane

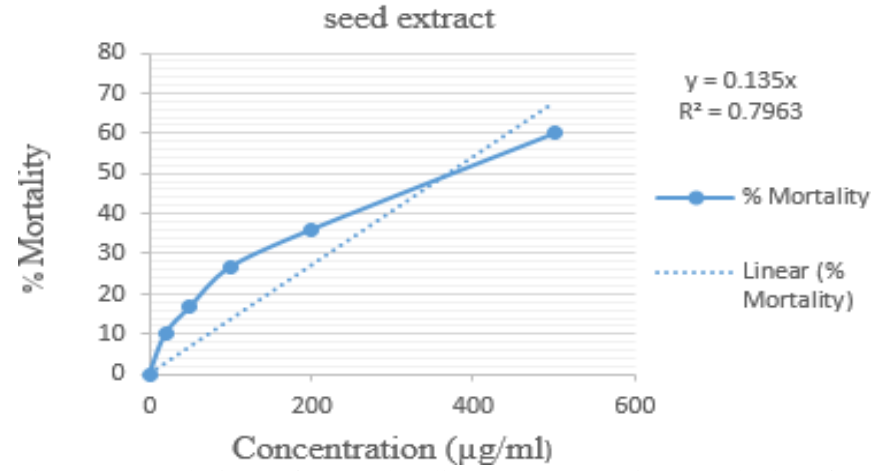

Fig. 4: Calculation of $\mathrm{LC}_{50}$ by linear - regression analysis of $n$ Hexane seed extract at different concentrations 


\section{Brime shrimp leathality bioassay of formulation}

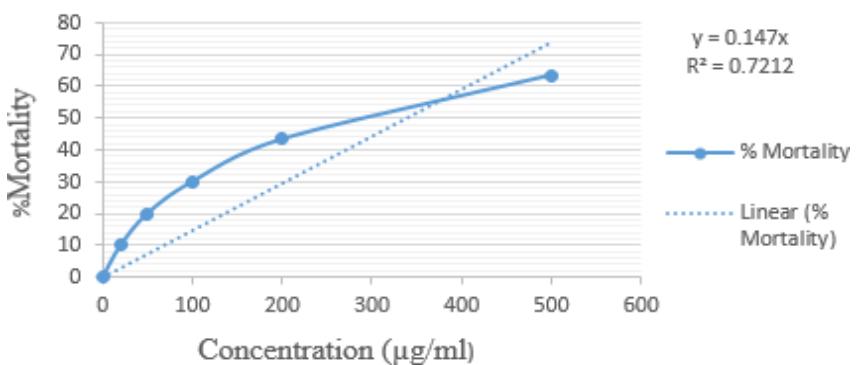

Fig. 5: Calculation of $\mathrm{LC}_{50}$ by linear- regression analysis of formulation at different concentrations

Table 10: Calculation of $\mathrm{LC}_{50}$ by linear - regression analysis

\begin{tabular}{cccc}
\hline Treatments & $\begin{array}{c}\text { Dose } \\
(\mu \mathrm{g} / \mathrm{ml})\end{array}$ & $\begin{array}{c}\text { Mean \% mortality after } \\
\text { 24 hours (Mean } \pm \text { SEM) }\end{array}$ & $\begin{array}{c}\mathbf{L C}_{50} \\
(\boldsymbol{\mu g} / \mathbf{m l})\end{array}$ \\
\hline \multirow{3}{*}{ Aqueous } & 20 & $10.00 \pm 0.5774$ & \\
pulp & 50 & $20.00 \pm 1.155$ & \\
& 100 & $26.51 \pm 0.5252$ & 370.64 \\
& 200 & $43.33 \pm 0.6755$ & \\
& 500 & $56.66 \pm 0.6640$ & \\
\hline
\end{tabular}

Table 11: Calculation of $\mathrm{LC}_{50}$ by linear - regression analysis of ethanol pulp extract

\begin{tabular}{cccc}
\hline Treatments & $\begin{array}{c}\text { Dose } \\
(\boldsymbol{\mu g} / \mathbf{m l})\end{array}$ & $\begin{array}{c}\text { Mean \% mortality after } \\
\text { 24 hours (Mean } \pm \text { SEM) }\end{array}$ & $\begin{array}{c}\mathbf{L C}_{50} \\
(\boldsymbol{\mu g} / \mathbf{m l})\end{array}$ \\
\hline \multirow{3}{*}{ Ethanolic } & 20 & $13.33 \pm 0.9930$ & \\
Pulp & 50 & $20.33 \pm 0.6009$ & \\
& 100 & $36.66 \pm 0.5833$ & 342.23 \\
& 200 & $46.66 \pm 0.3233$ & \\
\hline
\end{tabular}

Table 12: Calculation of $\mathrm{LC}_{50}$ by linear - regression analysis of $n$ Hexane seed extract

\begin{tabular}{cccc}
\hline Treatments & $\begin{array}{c}\text { Dose } \\
(\boldsymbol{\mu g} / \mathbf{m l})\end{array}$ & $\begin{array}{c}\text { Mean \% mortality after } \\
\text { 24 hours (Mean } \pm \text { SEM) }\end{array}$ & $\begin{array}{c}\mathbf{L C}_{50} \\
(\boldsymbol{\mu g} / \mathbf{m l})\end{array}$ \\
\hline \multirow{3}{*}{ N-hexane } & 20 & $10.00 \pm 0.6293$ & \\
seed & 50 & $16.66 \pm 0.6524$ & \\
& 100 & $26.44 \pm 0.4300$ & 370.37 \\
& 200 & $36.00 \pm 0.6178$ & \\
\hline
\end{tabular}

Table 13: Calculation of LC50 by linear - regression analysis of formulation

\begin{tabular}{|c|c|c|c|}
\hline Treatments & $\begin{array}{c}\text { Dose } \\
(\mu \mathrm{g} / \mathrm{ml})\end{array}$ & $\begin{array}{l}\text { Mean } \% \text { mortality after } \\
24 \text { hours (Mean } \pm \text { SEM) }\end{array}$ & $\begin{array}{c}\mathrm{LC}_{50} \\
(\mathrm{\mu g} / \mathrm{ml})\end{array}$ \\
\hline \multirow{5}{*}{ Formulation } & 20 & $10.00 \pm 1.299$ & \multirow{5}{*}{340.13} \\
\hline & 50 & $20.00 \pm 0.6351$ & \\
\hline & 100 & $30.00 \pm 0.5254$ & \\
\hline & 200 & $43.33 \pm 0.6755$ & \\
\hline & 500 & $63.66 \pm 0.3637$ & \\
\hline
\end{tabular}

Trypan blue dye cell exclusion assay (TBDCEA)

Effect of formulation on HeP-G2 cell line by TBDCEA: Control group showed number of viable cells, while in standard group lesser viable cells observed as compared to all other groups. Test- $1(100 \mu \mathrm{g} / \mathrm{ml})$ group showed lees no. of dead cells than Test-2 $(500 \mu \mathrm{g} / \mathrm{ml})$. In the present study, TBDCEA on crude extracts like aqueous, ethanolic, n-Hexane of pulp, seed, its combination and formulation of $A$. digitata $\mathrm{L}$ fruit were done, using three cell lines are MCF-7, HeP- G2, and COLO205. From table 14 the \% viability of cell by formulation showed highest cytotoxic activity than nhexane seed, Ethanolic pulp, and aqueous pulp extract
From above mentioned extracts specifically aqueous pulp, ethanol pulp, n-Hexane seed and formulation possesses significant result than other mentioned extract.

Table 14: Trypan blue dye cell exclusion assay of selected Adansonia digitata $L$ Fruit extracts on different cell lines

\begin{tabular}{|c|c|c|c|}
\hline \multirow{2}{*}{ Groups } & \multicolumn{3}{|c|}{$\%$ Viable cell count (Mean \pm SEM ) on cell lines } \\
\hline & MCF - 7 & HeP - G2 & COLO - 205 \\
\hline Control & $98.56 \pm 0.000^{* * * *}$ & $98.56 \pm 0.000^{\star * * *}$ & $98.56 \pm 0.000^{* * * *}$ \\
\hline $\begin{array}{l}\text { Standard } \\
(10 \mu \mathrm{g} / \mathrm{ml})\end{array}$ & $57.01 \pm 0.003^{* * * *}$ & $61.36 \pm 2.023^{* * * *}$ & $58.21 \pm 1.069^{* * * *}$ \\
\hline $\begin{array}{l}\text { Standard } \\
(100 \mu \mathrm{g} / \mathrm{ml})\end{array}$ & $44.43 \pm 0.857^{* * * *}$ & $48.21 \pm 0.5882^{* * * *}$ & $54.32 \pm 0.4455$ **** \\
\hline $\begin{array}{l}\text { Standard } \\
(500 \mu \mathrm{g} / \mathrm{ml})\end{array}$ & $23.25 \pm 0.6526^{* * * *}$ & $24.05 \pm 0.5780^{* * * *}$ & $25.14 \pm 0.4662^{* * * *}$ \\
\hline $\begin{array}{l}\text { Aq. Pulp } \\
(10 \mu \mathrm{g} / \mathrm{ml})\end{array}$ & $78.23 \pm 0.4388^{\# \# \# \#}$ & $73.21 \pm 0.4373^{\# \# \# \# ~}$ & 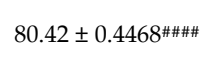 \\
\hline $\begin{array}{l}\text { Aq. Pulp } \\
(100 \mu g / m l)\end{array}$ & 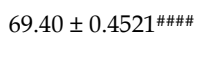 & $62.19 \pm 0.6483 \# \# \#$ & $70.47 \pm 0.4093$ \#\#\#\# \\
\hline $\begin{array}{l}\text { Aq. Pulp } \\
(500 \mu g / \mathrm{ml})\end{array}$ & $58.66 \pm 0.5702^{\# \# \#}$ & $54.64 \pm 04849$ \#\#\#\# & 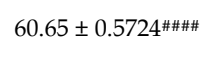 \\
\hline $\begin{array}{l}\text { Et. Pulp } \\
(10 \mu \mathrm{p} / \mathrm{ml})\end{array}$ & 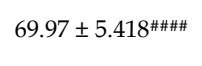 & $76.54 \pm 0.5989$ \#\#\#\# & 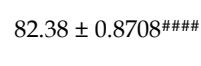 \\
\hline $\begin{array}{l}\text { Et. Pulp } \\
(100 \mu \mathrm{g} / \mathrm{ml})\end{array}$ & 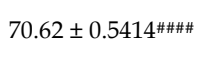 & $66.65 \pm 0.5730$ \#\#\#\# & $72.44 \pm 0.6091$ \#\#\#\# \\
\hline $\begin{array}{l}\text { Et. Pulp } \\
(500 \mu \mathrm{p} / \mathrm{ml})\end{array}$ & $60.43 \pm 0.6389$ \#\#\#\# & 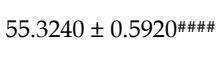 & $62.57 \pm 0.7322^{\# \# \# \# ~}$ \\
\hline $\begin{array}{c}\text { N-hexane } \\
\text { seed } \\
(10 \mu \mathrm{g} / \mathrm{ml})\end{array}$ & 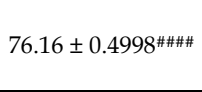 & 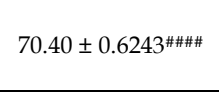 & 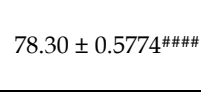 \\
\hline
\end{tabular}
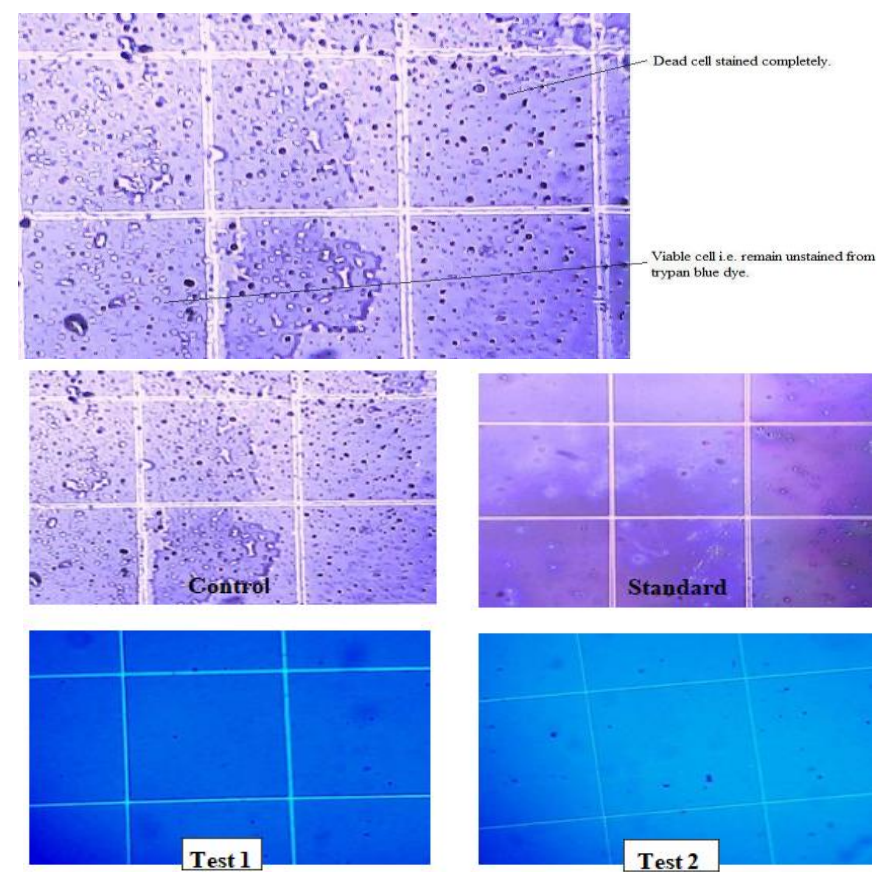

Fig. 6: Identification of viable and dead cell in TBDCEA cell exclusion

Trypan blue dye cell exclusion assay on MCF-7 Cell line
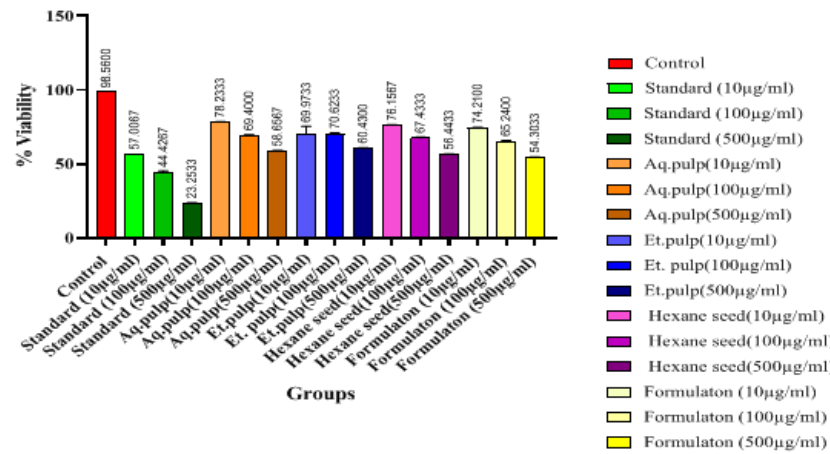

Fig. 7: Graph of TBDEA on MCF-7 cell line Int. J. Pharm. Sci. Drug Res. November-December, 2019, Vol 11, Issue 6 (358-369) 
The above figure 7 shows the cytotoxic activity of cytotoxic activity of $A$. digitata $\mathrm{L}$ fruit on MCF- 7 cell line. The cytotoxicity of formulation is higher than all other extract. As the percentage viability count of cell is ranges between $74.21 \pm 0.5670$ to $54.30 \pm 0.4506$ of $10 \mu \mathrm{g} / \mathrm{ml}$ to $500 \mu \mathrm{g} / \mathrm{ml}$ respectively which is significant when compared with control. And other extracts like Ethanolic pulp there percentage viability lies between $69.97 \pm 5.418$ to $60.43 \pm 0.6389$ with respect to dose dependent manner likewise the n-Hexane and Aqueous extracts of pulp and seed respectively possesses percentage inhibition in between $76.16 \pm 0.4998$ to 56.44 \pm 0.4290 and $78.23 \pm 0.4388$ to $58.66 \pm 0.5702$ respectively, which attains dose dependent manner.

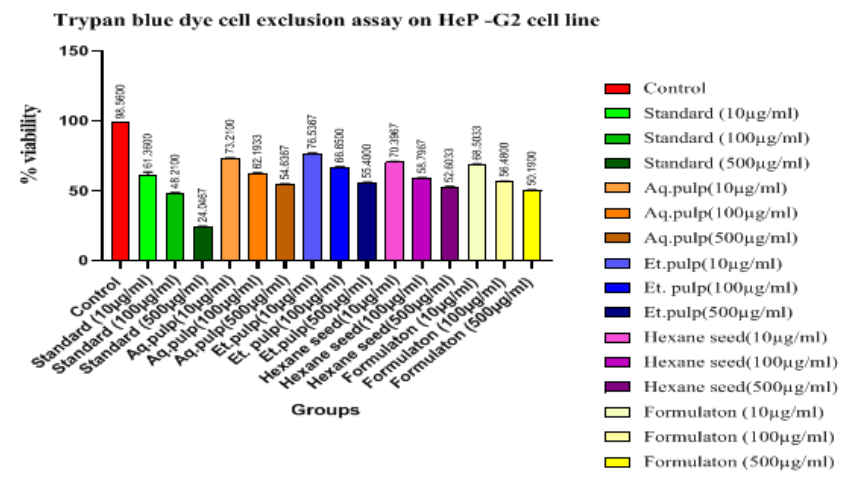

Fig. 8: Graph of TBDEA on HeP-G2 cell line

Trypan blue dye cell exclusion assay on Colo -205 cell line

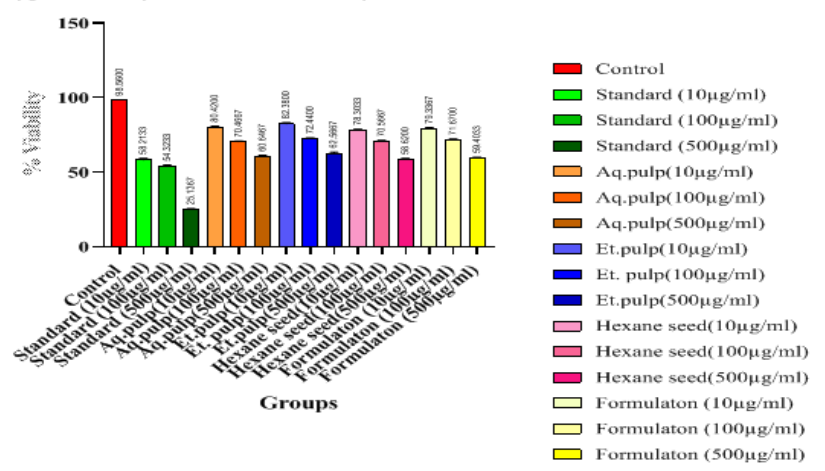

Fig. 9: Graph of TBDCEA on Colo-205 cell line

The above figure 8 shows the cytotoxic activity of $A$. digitata L fruit extracts and formulation on HeP-G2 cell line. The formulation Possesses highest cytotoxic effect than all other extract. As the percentage viability count of cell is ranges between $68.50 \pm 0.5748$ to $50.19 \pm 0.608$ of $10 \mu \mathrm{g} / \mathrm{ml}$ to $500 \mu \mathrm{g} / \mathrm{ml}$ respectively, which is more significant with compared to control and \% viability of extracts concentration of formulation $500 \mu \mathrm{g} / \mathrm{ml}$ possesses potent cytotoxic activity which is comparable to standard and whereas, other extracts like aqueous pulp, n-Hexane seed and Ethanolic pulp possessed percentage viability ranges between $73.21 \pm 0.4373$ to $54.64 \pm 0.4859,70.40 \pm 0.6243$ to $52.60 \pm 0.4605,76.54 \pm$ 0.5989 to $55.40 \pm 0.5920$ respectively, which attains dose dependent manner

The formulation shows higher toxic effect than all other extract, as percentage viability count of cell line is ranges between $79.34 \pm 0.5900$ to $59.40 \pm 0.6264$ of
$10 \mu \mathrm{g} / \mathrm{ml}$ to $500 \mu \mathrm{g} / \mathrm{ml}$ respectively. This found to be significant when compared with control. Whereas other extract of $A$. digitata $\mathrm{L}$ fruit like aqueous pulp, Ethanolic pulp and n-Hexane seed possesses percentage viability ranges between $80.42 \pm 0.4468$ to $60.65 \pm 0.5724,82.38 \pm$ 0.8708 to $62.57 \pm 0.7322$ and $78.30 \pm 0.5774$ to $58.62 \pm$ 0.6236 respectively, which attains dose dependent manner as shown in figure 9.

Finally from the result of TBDCEA suggest that the formulation of $A$. digitata $\mathrm{L}$ fruit comprised novel cytotoxic agent which will be potent therapeutic candidate for cancer of liver and it might be treatment of cancer specifically colon and breast cancer.

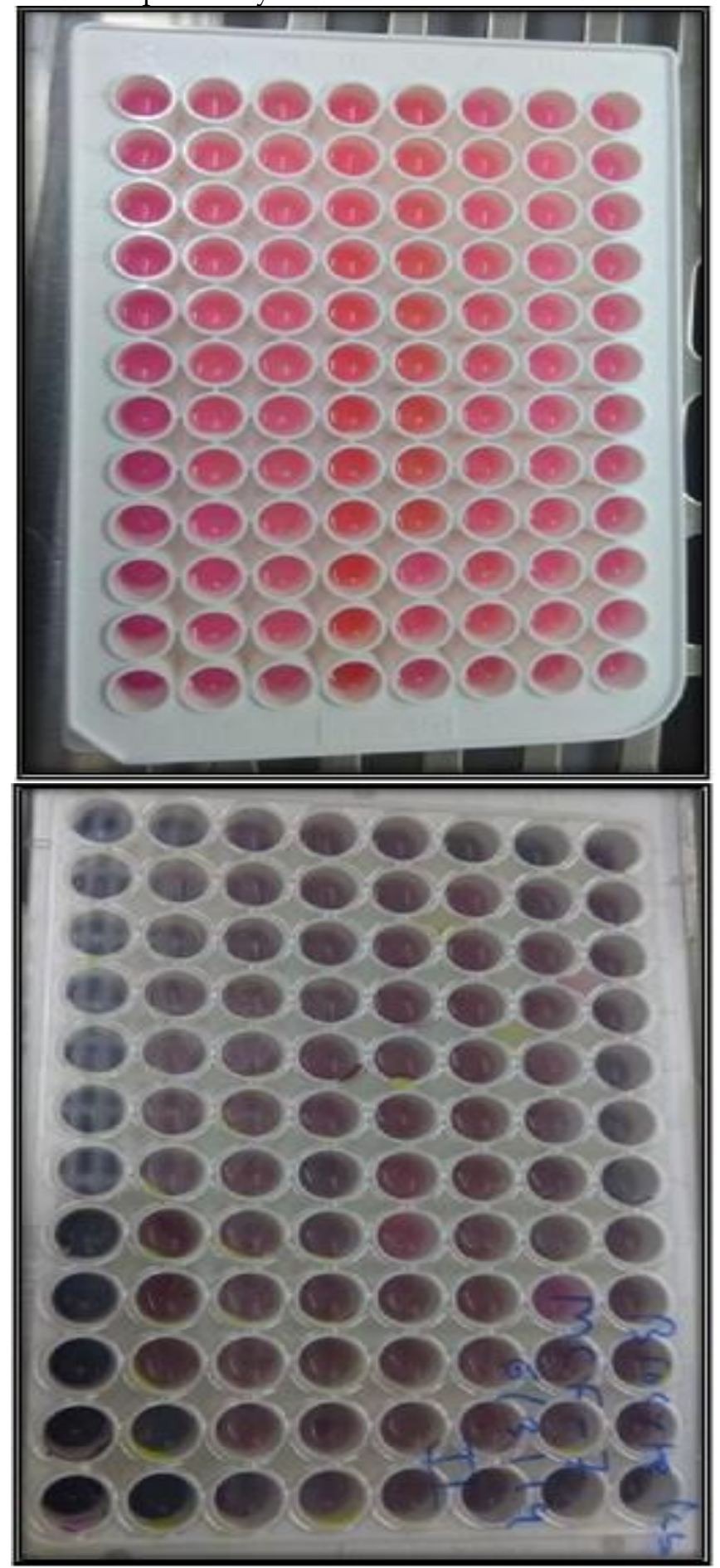

Fig. 10: MTT A and B show the colour of reaction mixture in, 96 well plates before and after the incubation periods respectively. 


\section{Micro culture tetrazolium assay}

The result of MTT assay on crude extracts like pulp, seed and combination of both. Cytotoxicity of Aqueous, Ethanol and n-Hexane of pulp, seed and its combination extracts and formulation of $A$. digitata $\mathrm{L}$ fruit were done, using three cell lines that are MCF-7, HeP-G2 and COLO-205. From above mentioned result specifically aqueous pulp, Ethanol pulp, n-Hexane seed and formulation possesses very significant cytotoxic activity. The formulation showed high cytotoxic activity than aqueous pulp, Ethanolic pulp and nhexane seed extract, which attains in order of Formulation > n-Hexane seed > Ethanol pulp > Aqueous pulp.

Table 15: MTT assay of selected A. digitata $\mathrm{L}$ fruit extracts on different cell lines

\begin{tabular}{|c|c|c|c|}
\hline \multirow{2}{*}{ Groups } & \multicolumn{3}{|c|}{$\%$ inhibition (Mean \pm SEM ) on cell lines } \\
\hline & MCF - 7 & HeP - G2 & COLO - 205 \\
\hline Control & 0.0 & 0.0 & 0.0 \\
\hline $\begin{array}{l}\text { Standard } \\
(20 \mu \mathrm{g} / \mathrm{ml})\end{array}$ & $52.48 \pm 0.000^{* \star * *}$ & $52.48 \pm 0.000^{* * * *}$ & $49.44 \pm 0.000^{* * * *}$ \\
\hline $\begin{array}{l}\text { Aq. Pulp } \\
(10 \mu \mathrm{g} / \mathrm{ml})\end{array}$ & $18.22 \pm 0.6091 \# \# \# \#$ & $23.20 \pm 0.6103 \# \# \# \#$ & $17.27 \pm 0.6336 \# \# \# \#$ \\
\hline $\begin{array}{l}\text { Aq. Pulp } \\
(100 \mu \mathrm{g} / \mathrm{ml})\end{array}$ & $22.53 \pm 0.7546 \# \# \# \#$ & $28.63 \pm 0.8206 \# \# \# \#$ & 21.28 土0.5143\#\#\#\# \\
\hline $\begin{array}{l}\text { Aq. Pulp } \\
(500 \mu \mathrm{g} / \mathrm{ml})\end{array}$ & 27.41 土 0.7814\#\#\#\# & $32.65 \pm 0.8022 \# \# \# \#$ & $25.43 \pm 0.5408 \# \# \# \#$ \\
\hline $\begin{array}{l}\text { Et. Pulp } \\
(10 \mu \mathrm{g} / \mathrm{ml})\end{array}$ & $16.39 \pm 0.4684 \# \# \# \#$ & $22.26 \pm 0.6076 \# \# \# \#$ & $15.60 \pm 0.7643 \# \# \# \#$ \\
\hline $\begin{array}{l}\text { Et. Pulp } \\
(100 \mu \mathrm{g} / \mathrm{ml})\end{array}$ & 19.64 土0.5777\#\#\#\# & $24.30 \pm 0.6248 \# \# \# \#$ & 17.78 土 0.6338\#\#\#\# \\
\hline $\begin{array}{c}\text { Et. Pulp } \\
(500 \mu \mathrm{g} / \mathrm{ml})\end{array}$ & $23.50 \pm 0.5301 \# \# \# \#$ & $29.59 \pm 0.5622 \# \# \# \#$ & $22.61 \pm 0.7844 \# \# \# \#$ \\
\hline $\begin{array}{l}\text { N-hexane seed } \\
(10 \mu \mathrm{g} / \mathrm{ml})\end{array}$ & $21.93 \pm 1.008 \# \# \# \#$ & $24.66 \pm 0.3805 \# \# \# \#$ & $17.59 \pm 0.6265 \# \# \# \#$ \\
\hline $\begin{array}{l}\text { N-hexane seed } \\
(100 \mu \mathrm{g} / \mathrm{ml})\end{array}$ & 24.59 士0.5956\#\#\#\# & $29.51 \pm 0.4096 \# \# \# \#$ & $22.58 \pm 0.5790 \# \# \# \#$ \\
\hline $\begin{array}{l}\text { N-hexane seed } \\
(500 \mu \mathrm{g} / \mathrm{ml})\end{array}$ & $28.85 \pm 0.5427 \# \# \# \#$ & $34.71 \pm 0.6327 \# \# \# \#$ & $25.82 \pm .6505 \# \# \# \#$ \\
\hline $\begin{array}{l}\text { Formulation } \\
(10 \mu \mathrm{g} / \mathrm{ml})\end{array}$ & $22.57 \pm 0.7960 \# \# \# \#$ & $25.85 \pm 0.5239$ \#\#\#\# & $20.75 \pm 0.5418 \# \# \# \#$ \\
\hline $\begin{array}{c}\text { Formulation } \\
(100 \mu \mathrm{g} / \mathrm{ml})\end{array}$ & $25.69 \pm 0.4478 \# \# \# \#$ & $32.78 \pm 0.6423 \# \# \# \#$ & $23.40 \pm 0.3996 \# \# \# \#$ \\
\hline $\begin{array}{c}\text { Formulation } \\
(500 \mu \mathrm{g} / \mathrm{ml})\end{array}$ & $29.96 \pm 0.3571 \# \# \# \#$ & $37.81 \pm 0.6614 \# \# \# \#$ & $27.34 \pm 0.8764 \# \# \# \#$ \\
\hline
\end{tabular}

Values are expressed Mean \pm SEM and $\mathrm{n}=3$, ${ }^{* * * *} P<0.0001$ using one way - ANOVA coupled with "Dunnett $t$ test", criterion for significance. ${ }^{* * * *} P<0.0001$ is considered as significant when standard group compared with control group and \#\#\#\# indicate test groups compared with control group.

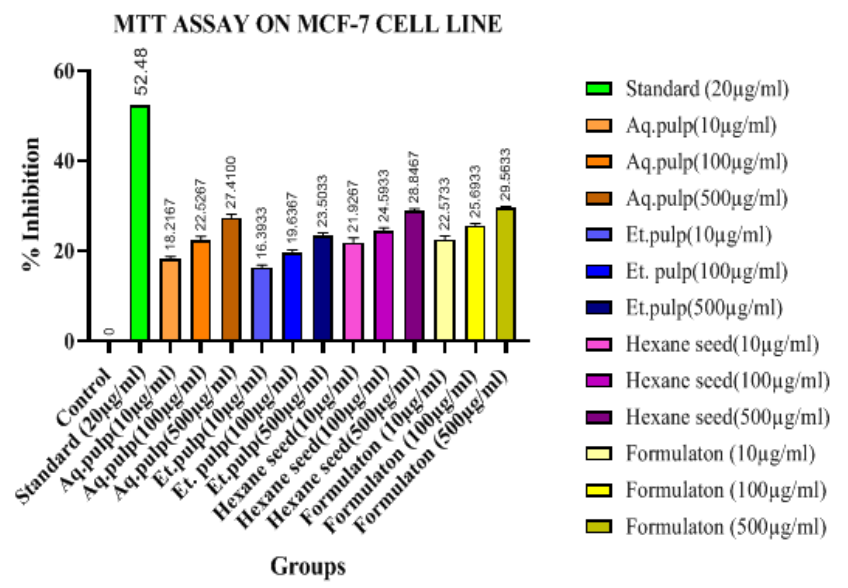

Fig. 11: Graph of MTT Assay on MCF-7 cell line

Above figure 11 shows the cytotoxic activity of $A$. digitata L fruit extract and formulation on MCF-7 cell line. The cytotoxicity of formulation shows higher activity than all other extract. As the percentage inhibition by formulation was ranges between $22.57 \pm$ 0.7960 to $29.96 \pm 0.3571$ which is significant when compared with control. And other extract like Ethanolic pulp, n-Hexane seed, and aqueous pulp extracts exhibits gradual increasing in the cytotoxicity activity (percentage inhibition) with respect to dose dependent manner.

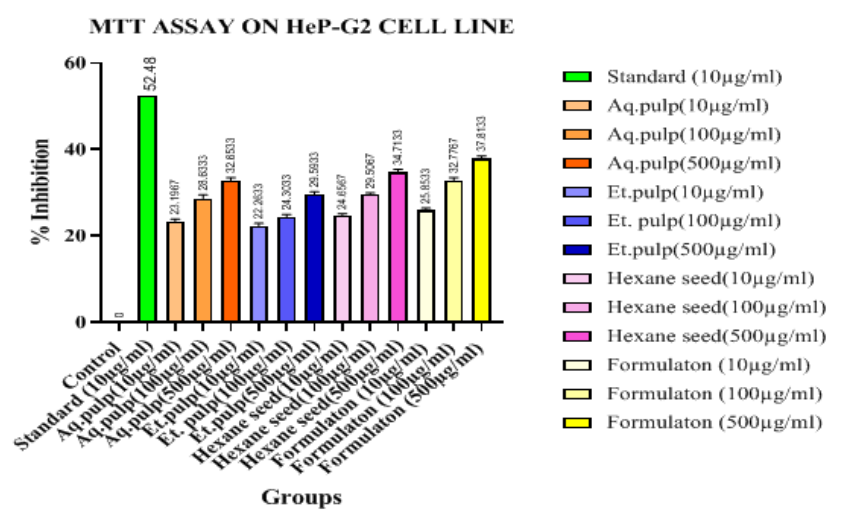

Fig. 12: Graph of MTT Assay on HeP- G2 cell line

Above fig. 12 shows cytotoxicity activity of $A$. digitata $\mathrm{L}$ fruit extracts and formulation on HeP-G2 cell line. The cytotoxicity of formulation shows highest activity than other extracts. As the percentage inhibition by formulation were ranges between $25.85 \pm 0.5239$ to $37.81 \pm 0.6614$ which is more significant $\left({ }^{* * *} P<0.0001\right)$ when compared with control. And the percentage inhibition by $500 \mu \mathrm{g} / \mathrm{ml}$ concentration of formulation gives significant cytotoxicity with respect to standard. Other extract like Ethanolic pulp, n-Hexane seed, and Aqueous pulp extracts exhibits gradual increasing in the cytotoxic activity (percentage inhibition) ranges between $22.26 \pm 0.06076$ to $29.56 \pm 0.5622,24.66 \pm 0.3805$ to $34.71 \pm 0.6327,23.20 \pm 0.6103$ to $32.65 \pm 0.8022$ respectively in dose dependent manner.

MTT ASSAY ON COLO -205 CELL LINE

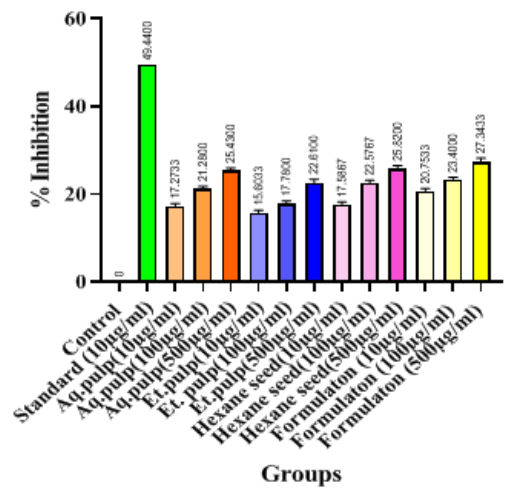

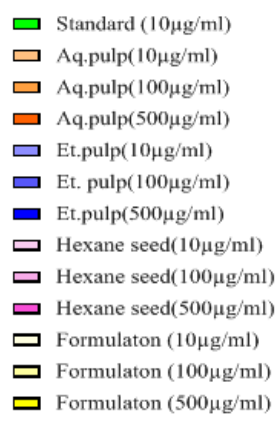

Fig. 13: Graph of MTT Assay on Colo-205 cell line

Above figure shows the cytotoxic activity of $A$. digitata L fruit extract and formulation on COLO- 205 cell line. The cytotoxicity of formulation shows highest activity than other extracts as the percentage inhibition by formulation were ranges between $20.75 \pm 0.5418$ to $27.34 \pm 0.864$ which is significant when compared with control. And other extracts like Ethanolic pulp, nHexane seed, and aqueous pulp exhibits gradual 
increasing in the cytotoxic activity (percentage inhibition) with respect to dose dependent manner.

Finally the present study suggests that the formulation of $A$. digitata $\mathrm{L}$ fruit comprised novel cytotoxic agent which will be potent therapeutic drug for liver cancer.

Quantitation of active ingredients from extract

Vit. C

Identification of Ascorbic acid from aqueous pulp extract by chemical method

The identification of ascorbic acid from aqueous pulp extract was done by using chemical method. It was indicate that vitamin C (ascorbic acid) present in aqueous pulp extract.

Table 16: Identification of Ascorbic acid from aqueous pulp extract

\begin{tabular}{|c|c|c|c|}
\hline $\begin{array}{l}\text { S. } \\
\text { No }\end{array}$ & Test & Observation & Inference \\
\hline 1. & $\begin{array}{l}1 \mathrm{ml} \text { diluted solution of aqueous } \\
\text { pulp extract then added some } \\
\text { drops of } 5 \% \mathrm{w} / \mathrm{v} \text { sodium fresh } \\
\text { nitroprusside solution and } 2 \mathrm{ml} \\
\text { dil.NaOH solution. Add } 0.6 \mathrm{ml} \text { of } \\
\text { HCL dropwise and stirred, the } \\
\text { Yellow colour turned to blue. }\end{array}$ & $\begin{array}{l}\text { Yellow } \\
\text { colour } \\
\text { turned to } \\
\text { blue. }\end{array}$ & $\begin{array}{c}\text { Vit.C } \\
\text { present }\end{array}$ \\
\hline 2. & $\begin{array}{l}\text { Diluted solution of extract } \\
\text { solution to it add few ml of 2,6- } \\
\text { dichlorophenolindophenol } \\
\text { solution, the solution is } \\
\text { decolourised }\end{array}$ & $\begin{array}{l}\text { The solution } \\
\text { is } \\
\text { decolourised }\end{array}$ & $\begin{array}{l}\text { Vit.C } \\
\text { present }\end{array}$ \\
\hline
\end{tabular}

Determination of Vit. C from aqueous pulp extract by Titration method

Standard Vit. C and aqueous pulp extract was determined by using titration method. The result of this method Shows that the \% content of ascorbic in aqueous pulp extract which was found to be $6.1 \%$.

Table 17: Determination of Vitamin C (Ascorbic acid)

\begin{tabular}{ccccc}
\hline $\begin{array}{c}\text { S. } \\
\text { No. }\end{array}$ & $\begin{array}{c}\text { Name of } \\
\text { sample }\end{array}$ & $\begin{array}{c}\text { Burette } \\
\text { reading }\end{array}$ & $\begin{array}{c}\text { \% content } \\
\text { of Ascorbic } \\
\text { acid (w/w) }\end{array}$ & $\begin{array}{c}\text { Normal } \\
\text { Range }\end{array}$ \\
\hline 1 & $\begin{array}{c}\text { Standard } \\
\text { Ascorbic Acid }\end{array}$ & 11.4 & 100 & $99.0 \%$ to \\
2 & $\begin{array}{c}\text { Aqueous pulp } \\
\text { extract }\end{array}$ & 0.7 & 6.1 & $100.5 \%$ \\
\hline
\end{tabular}

\section{Squalene}

Identification of Squalene from $n$-hexane seed extract by thin layer chromatography

Thin layer chromatographic analysis of n- hexane seed extracts were carried out by using various types of solvent systems. This extract shows 1 spot at a selected mobile phase. TLC was performed qualitatively to identify the various elements in the extract. TLC was done for $\mathrm{n}$ - hexane seed extract and the extract showed 1 spots with the Rf value of 0.94 . These can compared with Rf value of standard squalene i.e. 0.90 which shows that present of squalene in n- hexane seed extracts.

Table 18: Identification of Squalene

\begin{tabular}{ccc}
\hline S. No & Samples & Rf values \\
\hline 1. & Standard sample & 0.9 \\
2. & Test sample & 0.94 \\
\hline
\end{tabular}

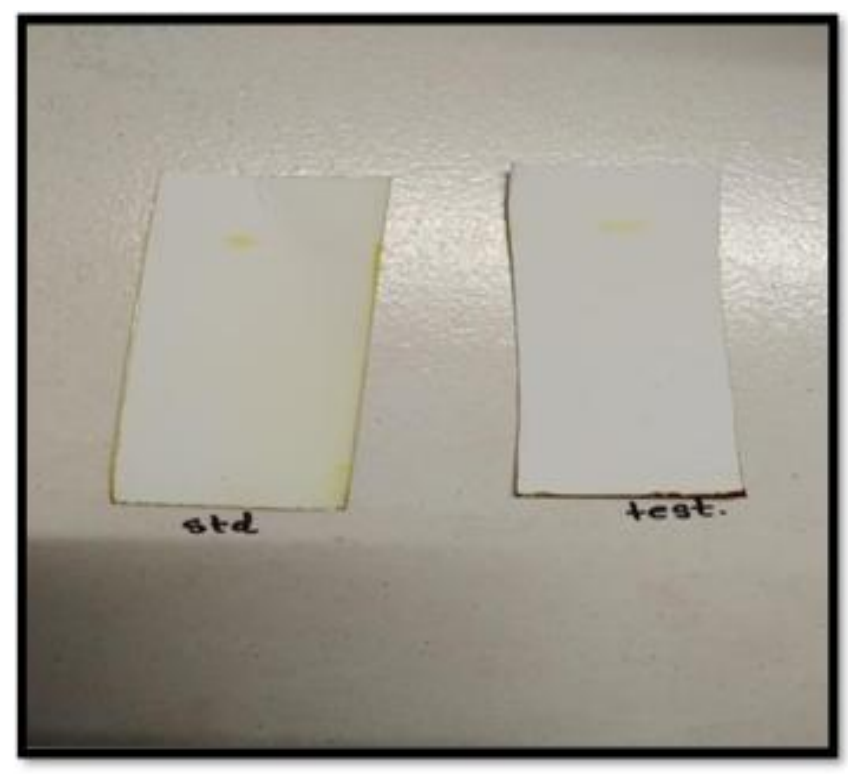

Fig. 14: Photos of Standard and test sample in TLC plate

Determination of Squalene from $\mathrm{n}$-Hexane seed extract by HPLC Method

Standard Squalene and seed extract determined by using HPLC method. The result of this method Shows that the \% amount of squalene in $\mathrm{n}$-hexane seed extract which was found to be $48 \%$.

\begin{tabular}{lccc}
\multicolumn{4}{l}{ Table 19: } \\
\hline S. No & Sample Name & Peak Area & \% content of Squalene \\
\hline 1 & Standard Squalene & $3905.58^{*}$ & 100 \\
2 & N- hexane seed & 1877.089 & 48 \\
extract & & \\
\hline
\end{tabular}

*Mean of 3 determination

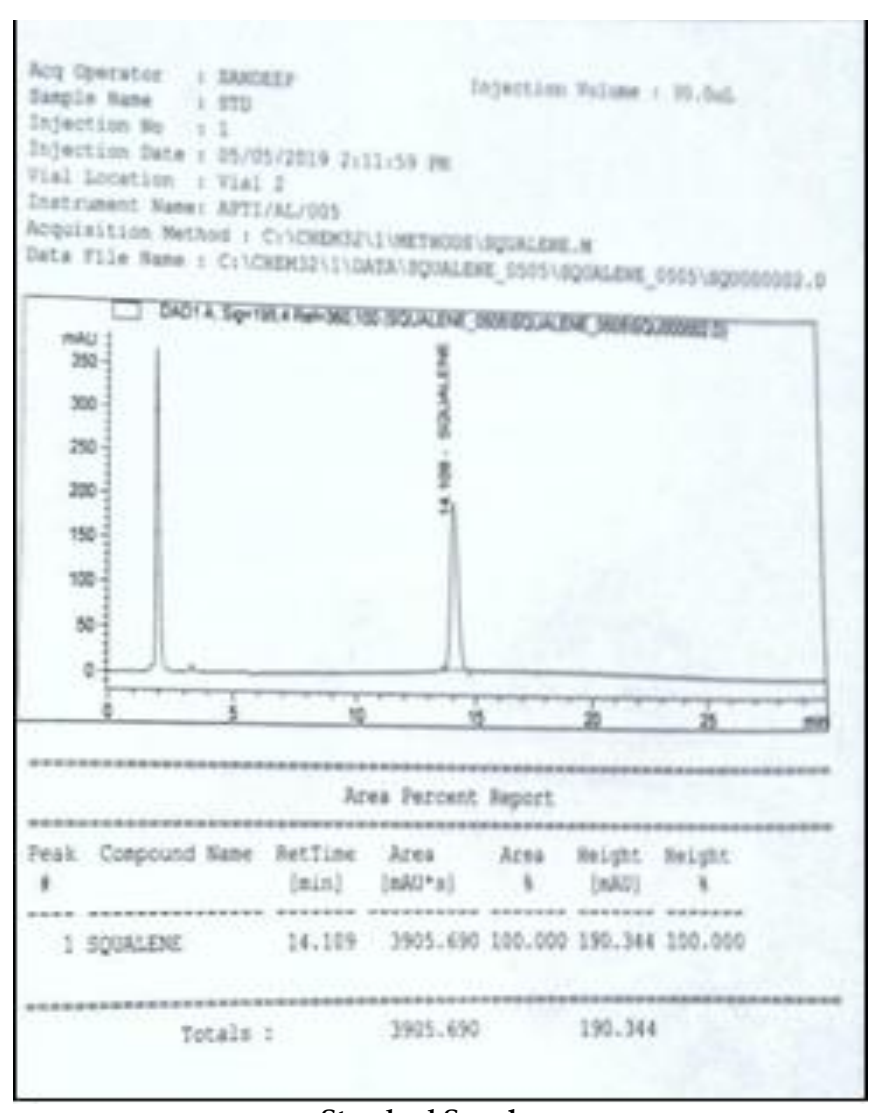

Standard Squalene 
Sandeep Dilip Kadam et al. / Evaluation of In-vitro Anticancer Activity and Quantitation of Active

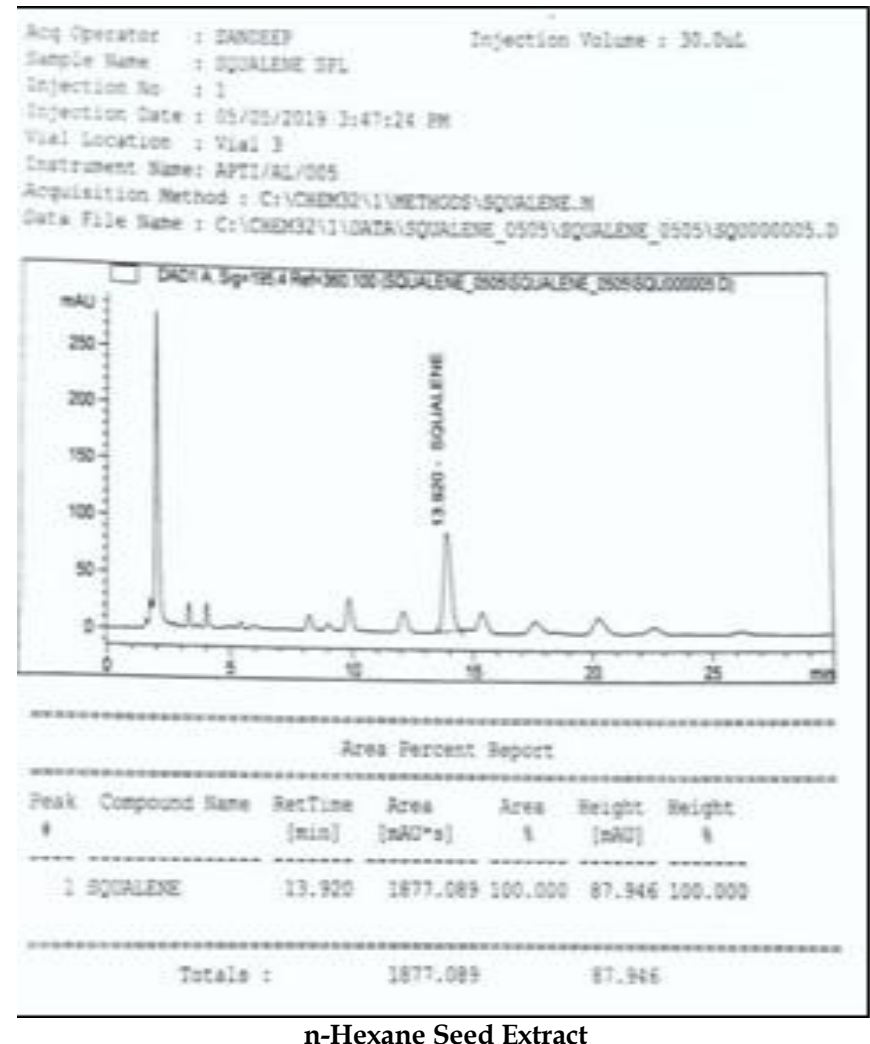

Fig. 15: Chromatogram for Analysis of Standard Squalene and nhexane seed extract from $A$. digitata $\mathrm{L}$. fruit

\section{REFERENCES}

1. Definition of Cancer [Internet] 2018. Available From: <http://www.who.int/cancer/en. (Accessed on: 10 Dec 2018).

2. Rajpal S, Kumar A, William J. Economic burden of cancer in India: Evidence from cross-sectional nationally representative household survey. 2014, PloS One, 2018; 13 (2): 1-17.
3. Sudhakar. A. History of cancer, Ancient and Modern Treatment Methods. Journal of cancer Science \& Therapy. 2009; 01(02): 1-4.

4. Desai AG, Qazi GN, Ganju RK, Mahmoud ET, Singh J, Saxena AK, Bedi YS, Taneja SC, Bhat HK. Medicinal Plants and Cancer Chemoprevention Current Drug Metabolism. NIH Public Access Author Manuscript. 2008; 9(7): 581-591.

5. Greenwell M, Rahman PKSM. Medicinal Plants: Their Use in Anticancer Treatment. International Journal Pharmaceutical Science Research. 2015; 6(10): 4103-4112.

6. Sundarambal M, Muthusamy $P$, Radha R, Jerad SA. A review on Adansonia digitata Linn. Journal of Pharmacognosy and Photochemistry. 2015; 4 (4): 12-16.

7. Photo Trade, "Baobab Dried Fruit Pulp - An application For Novel Food Approval in the EU as a Food Ingredient", Herbal Science International Ltd, 2006.

8. Donkor AM, Addae D, Kaponau EJ, Kankam F, Boaudi NA, Abanya Manu YE. Antioxidant Enrichment of Baobab Fruit pulp treated with oil extracted from the seed. Food and Nutrition Science. 2014; 5: 328-333.

9. ShyleshPadikkala.[Internet]2000.Availablefrom;http://Shod hganga.inflibnet.ac.in/bitstream/10603/ 139411/13/13;material\%20method 20\%20105-129 pd [Accessed on:10 sep.2018].

10. Meyer BN, Ferrigni NR, Putnam JE, Jacobsen LB, Nichols DJ, McLaughlin JL. Brine shrimp: A convenient general bioassay for active plant constituents. Planta medica. 1982; 45 (05): 3140

11. Kini S, Swain SP, Gandhi AM. Synthesis and Evaluation of Novel benzothiazole derivative against human cervical cancer cell line. Indian Journal of Pharmaceutical sciences. 2007; 69(1):46-47.

12. Khandelwal KR. Practical Pharmacognosy. Ed. 22. Pune: Nirali Prakashan; 2012. p. 25.1-25.9.

13. Indian Pharmacopoeia 2007, Vol II, 124-125.

14. Han-Ping He, Harold C, Yizhong Li, Meisun. Extraction and Purification of Squalene from Amaranths Grain. Journal of Agricultural and Food Chemistry. 2002; 50:368-372.

15. Bavisetty SCB, Narayan B. An Improved RP-HPLC method for simultaneous analyses of squalene and cholesterol especially in aquatic food. Journal of Food Sciences and Technology. 2015; 52(9):6083-6089.

HOW TO CITE THIS ARTICLE: Kadam SD, Kondawar MS. Evaluation of In-vitro Anticancer Activity and Quantitation of Active Ingredient of Adansonia digitata L. Fruit. Int. J. Pharm. Sci. Drug Res. 2019; 11(6): $358-369$. DOI: 10.25004/IJPSDR.2019.110613 